\title{
Kortikosteroidi kod teške pneumonije
}

\section{Corticosteroids in severe pneumonia}

\author{
Viktor Kotarski \\ Klinika za infektivne bolesti „Dr. Fran Mihaljević,' Zagreb
}

Ključne riječi:

Kortikosteroidi

Pneumonija

Keywords:

Corticosteroids

Pneumonia

Primljeno: 02.12.2019

Received: 02.12.2019.

Prihvaćeno: 05.01 .2020$.

Accepted: 05.01.2020.

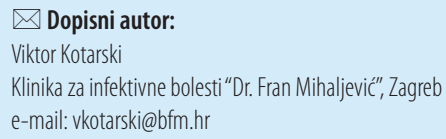

\begin{abstract}
Sažetak
Pneumonija iz opće populacije je još uvijek uzrok značajnog morbiditeta i mortaliteta, usprkos učinkovitoj antimikrobnoj terapiji. Smatra se da je neuspjeh u liječenju, barem djelomično, uzrokovan pretjeranim upalnim odgovorom na infekciju. Kortikosteroidi su se do sada pokazali djelotvornima u smirivanju upale i poboljšanju ishoda liječenja nekoliko infektivnih bolesti. Stoga su, također, provedene brojne studije na temelju kojih je ispitivan utjecaj kortikosteroida na ishod liječenja bolesnika s pneumonijom iz opće populacije. lako je većina studija pokazala pozitivan efekt u smislu bržeg postizanja kliničke stabilnosti, skraćenja vremena hospitalizacije ili antimikrobne terapije, u većini njih nije pronađena razlika u smrtnosti. lako se u novim smjernicama iz 2019. godine za liječenje pneumonije (IDSA i NICE) ne preporučuje rutinsko davanje kortikosteroida, pojedini ih stručnjaci ipak preporučuju kao opciju u liječenju isključivo teške pneumonije, uz napomenu kako je potrebno istražiti koje će skupine bolesnika imati najviše koristi od kortikosteroida te optimalnu dozu i trajanje liječenja.
\end{abstract}

\begin{abstract}
Summary
Community acquired pneumonia (CAP) remains a significant cause of morbidity and mortality despite appropriate antimicrobial treatment. Treatment failure is, at least in part, caused by excessive inflammatory response to infection. Corticosteroids have been proven effective in improving treatment outcomes in several infectious diseases. With this rationale, many studies have been conducted to determine whether the immunomodulatory effect of steroids would also be beneficial in treatment of CAP. Although many studies did demonstrate shorter time to clinical stability, shorter antimicrobial treatment, and shorter hospitalization, most of them have failed to demonstrate survival benefit. Generally speaking, the latest guidelines for treatment of CAP (published in 2019 by IDSA and NICE, respectively) do not recommend the routine use of corticosteroids, but some experts still recommend their use in case of severe CAP. Further studies are needed to determine which groups of patients are most likely to benefit from corticosteroids and what are the optimal dose and duration of treatment.
\end{abstract}

Uvod

Pneumonija iz opće populacije treći je najčešći uzrok smrti na globalnoj razini, odmah poslije kardiovaskularnih i malignih bolesti. ${ }^{[1]}$ Usprkos učinkovitoj antimikrobnoj terapiji, stopa mortaliteta i dalje je relativno visoka, čak i u industrijaliziranim zemljama Europe i Sjeverne Amerike. Mortalitet hospitaliziranih bolesnika s pneumonijom i dalje je oko $10 \%$, a u jedinicama intenzivne skrbi i viši od 30\%. ${ }^{[2],[3]}$ Smatra se kako je neuspjeh liječenja često, barem djelomično, uzrokovan pretjeranim lokalnim i sustavskim upalnim odgovorom na infekciju. Većina antibiotika djeluje na uzročnika pneumonije, ali nema nikakvog utjecaja na upalni odgovor. Stoga se već desetljećima traga za najboljom metodom regulacije upale kojom bi se potencijalno spriječilo pretjerano oštećenje plućnog parenhima i multiorganska disfunkcija koja nastaje kao posljedica sepse odnosno upalnog odgovora sustava u sklopu teške pneumonije. Primjerice, veći je broj studija pokazao kako imunomodulacijsko djelovanje makrolida poboljšava ishod liječenja teške pneumonije. ${ }^{[4]}$ Također, kortikosteroidi su se pokazali djelotvornima u smanjivanju upale i poboljšanju ishoda liječenja nekoliko infektivnih bolesti (pneumokokni meningitis, tuberkulozni meningoencefalitis, P. jirovecii pneumonija). ${ }^{[5],[6]}$ Stoga su u posljednjih desetak godina provedene brojne studije na temelju koje su pokušale utvrditi učinak kortikosteroida na ishod liječenja bolesnika s pneumonijom iz opće populacije. Antiinflamatorno djelovanje kortikosteroida temelji se na snižavanju sinteze proinflamatornih citokina (IL-8, IL-6) i poticanju sinteze antiinflamatornih citokina (IL-10). Kortikosteroidi, također, kompenziraju relativnu adrenalnu insuficijenciju kod teških bolesti, uključujući sepsu. 
Glavno pitanje u većini studija bilo je imaju li kortikosteroidi bilo kakvog učinka na ishod liječenja pneumonije, prvenstveno u smislu snižavanja mortaliteta, skraćenja vremena hospitalizacije ili smanjenja učestalosti komplikacija. Međutim, kako bi se istraživanja uopće mogla provesti, a kasnije i usporediti automatski su za svaku studiju postavljena pitanja osnovnog koncepta i organizacije ispitivanja, poput metode odabira bolesnika kod kojih će se primjenjivati kortikosteroidi, koji će se kortikosteroidi koristiti, u kojoj dozi i koliko dugo. Već se u tim temeljnim postavkama studije značajno međusobno razlikuju, što u velikoj mjeri otežava donošenje jasnog zaključka i preporuka za praksu.

Od studija provedenih u posljednjih desetak godina, vrijedi posebno istaknuti tri velike randomizirane studije i dvije metaanalize koje su u velikoj mjeri utjecale na najnovije preporuke o primjeni kortikosteroida kod teške pneumonije.

Godine 2010. u časopisu American Journal of Respiratory and Critical Care objavljena je dvostruko slijepa randomizirana klinička studija s ukupno 213 bolesnika s pneumonijom iz opće populacije. ${ }^{[7]}$ Prva je skupina liječena prednizolonom u dozi od $1 \times 40 \mathrm{mg} u$ trajanju od 7 dana, a druga placebom. Uspoređena je stopa izlječenja nakon 7 dana liječenja. Iako je u skupini liječenoj prednizolonom zabilježen raniji pad febriliteta i upalnih parametara, rezultati su pokazali da se stopa izlječenja nakon 7 dana $(81.4 \%$ vs. $85.3 \% ; \mathrm{P}=0.47)$ i mortalitet nakon 30 dana ( $6.2 \%$ vs $5.9 \% \mathrm{P}=0.93)$ nisu značajno razlikovali, ali u skupini s prednizolonom češće je došlo do ponovnog pogoršanja simptoma nakon 7 dana u usporedbi sa skupinom koja je liječena placebom ( $19.2 \%$ vs $6.2 \% \mathrm{P}=0.04)$. Sukladno tomu, iako je inicijalno postignut brži pad CRP-a, kod skupine bolesnika liječene prednizolonom, CRP je 14 dana nakon početka liječenja u prosjeku bio viši nego kod skupine liječene placebom $(41.73+/-64.98$ vs. $22.05+/-53.32$ $\mathrm{mg} / \mathrm{L} ; \mathrm{P}=0.01$ ). Kod bolesnika s pneumokoknom pneumonijom zabilježena je višestruko povećana učestalost kasnog pogoršanja između 7. i 30. dana od početka liječenja, ako su bili liječeni prednizolonom $(26.2 \%$ vs. $5.6 \% \mathrm{P}=0.02$ ). S obzirom na sve navedeno, postavlja se pitanje je li privremeno poboljšanje samo rezultat simptomatskog djelovanja kortikosteroida kojim se maskira klinička slika i odgađa upalni odgovor. Može li privremeno smanjenje upale u konačnici dovesti do sporijeg razješavanja infekcije, pogotovo kod bolesnika s pneumokoknom pneumonijom? Ima li produljeno i postupno smanjivanje doze kortikosteroida smisla i može li se njime izbjeći ponovna odnosno odgođena upala i bi li to imalo utjecaja na ishod liječenja?

Iako u ovoj studiji nije pronađena razlika u mortalitetu između dviju skupina, nije isključena mogućnost da ipak postoji učinak kortikosteroida na mortalitet koji se jednostavno ne može detektirati na ovako malom broju ispitanika.

U multicentričnoj randomiziranoj studiji objavljenoj u časopisu JAMA 2015. (Torres et al.) analiziran je utjecaj kortikosteroida na stopu ranog (unutar 72h) i kasnog (72-120h) neuspjeha u liječenju bolesnika s teškom pneumonijom. ${ }^{\left[{ }^{8]}\right.}$ Teška pneumonija definirana je kao V. stupanj Pneumonia Severity Index-a (PSI) uz $\mathrm{CRP}>150 \mathrm{mg} / \mathrm{L}$. Korišten je prednizolon u dozi $2 \times 0,5$ $\mathrm{mg} / \mathrm{kg}$ per os u trajanju od 5 dana. Rezultati su pokazali da prednizolon dovodi do smanjenja učestalosti kasnog neuspjeha liječenja (OR 0.34, 95\% CI 0.14-0.87, $\mathrm{P}=0.02)$. Međutim, jedina varijabla za procjenu neuspjeha u liječenju koja je pokazala statistički značajnu razliku između skupina bila je prisutnost radiološke progresije infiltrata na plućima ( $2 \%$ vs $14 \%, \mathrm{p}=0.03$ ). Ostale četiri varijable za procjenu kasnog neuspjeha liječenja (progresija respiratorne insuficijencije, potreba za mehaničkom ventilacijom, pojava septičkog šoka ili smrt) nisu pokazale statistički značajnu razliku. Zabilježen je trend manje učestalosti kasnog razvoja septičkog šoka kod bolesnika liječenih prednizolonom koji nije statistički značajan ( $0 \%$ vs $7 \%, \mathrm{p}=0.12)$.

Kod skupine liječene prednizolonom također je nađen veći pad upalnih parametara (CRP, IL-10), treći dan nakon početka liječenja. Budući da je u nekoliko ranijih studija, uključujući i ranije opisanu studiju Snijders et al. iz 2010. godine ${ }^{[7],[9]}$ opisan ponovni porast upalnih parametara nakon završetka liječenja kortikosteroidima, u ovoj su studiji ponovljena mjerenja upalnih parametara sedmi dan od početka liječenja i pad je i dalje bio izraženiji kod skupine liječene prednizolonom.

Iako ni u ovoj studiji nije pronađena razlika u mortalitetu između skupina ( $9 \%$ vs $15 \% \mathrm{P}=0.37$ ), njeni autori naglašavaju da bi za procjenu eventualnog utjecaja kortikosteroida na mortalitet bio potreban daleko veći broj ispitanika.

European Respiratory Journal je 2016. godine objavio studiju (Wirz et al.) u kojoj je analiziran utjecaj prednizolona na liječenje različitih podskupina bolesnika koje su razvrstane prema dokazanom uzročniku pneumonije, antimikrobnoj terapiji i inicijalnoj vrijednosti prokalcitonina ${ }^{[8]}$ Ispitanici su primali prednizon u dozi 1 x $50 \mathrm{mg}$ per os kroz 7 dana ili placebo. Uspoređeno je vrijeme do postizanja kliničke stabilnosti odnosno do stabilizacije vitalnih parametara koji su mjereni u intervalima od $12 \mathrm{~h}$. Pokazalo se kako je skupina liječena prednizonom imala statistički značajno kraće vrijeme do postizanja kliničke stabilnosti, neovisno o etiologiji pneumonije (medijan 3.4 vs 4.4 dana, OR 1.36, 95\% CI 1.03-1.08), ulaznom prokalcitoninu 
(medijan 2.6 vs 4.5 dana, OR 1.75, 95\% CI 1.37-225) i tjelesnoj temperaturi (medijan 2.5 vs 4.0 dana, OR 1.27, 95\% CI 1.05-1.54), što sugerira da povoljan učinak steroida nije samo posljedica isključivo simptomatskog odnosno antipiretskog djelovanja. U ovoj studiji nije utvrđen negativan utjecaj kortikosteroida na ishod liječenja bolesnika s influenca pneumonijom, što je u suprotnosti s ranije objavljenim studijama koje povezuju primjenu kortikosteroida s povećanom stopom smrtnosti u influenca pneumoniji. ${ }^{[1]}$

Međutim, ponovno je u podskupini bolesnika s pneumokoknom pneumonijom učinak prednizona na brže postizanje kliničke stabilnosti bio slabije izražen, u skladu s ranije opisanom studijom Snijders et al. iz 2010. godine. Prednizon je čak povezan s duljim trajanjem antimikrobnog liječenja i povećanom učestalošću ponovne hospitalizacije kod bolesnika s pneumokoknom pneumonijom koji su liječeni antibiotskom terapijom koja nije uključivala makrolid.

Rezultati navedenih studija koji sugeriraju da je možebitni pozitivni učinak kortikosteroida najmanje izražen ili čak odsutan u liječenju pneumokokne pneumonije posebno su iznenađujući, budući se primjena kortikosteroida već ranije pokazala korisnom u liječenju pneumokoknog meningitisa [6] i već je ranije opisan pozitivan učinak kortikosteroida na liječenje teške pneumonije iz opće populacije u kojoj je S. pneumoniae jedan od najčešćih uzročnika. ${ }^{[12]}$

$\mathrm{S}$ ciljem donošenja jasnijih preporuka o primjeni kortikosteroida u liječenju pneumonije, nedavno su objavljene dvije metaanalize; metaanaliza Cochraneove baze iz 2017. obuhvatila je 17 randomiziranih studija s ukupno 2300 bolesnika. ${ }^{[13]}$ Rezultati metaanalize pokazali su kako kortikosteroidi značajno smanjuju smrtnost bolesnika s teškom pneumonijom (RR 0.58, $95 \%$ CI 0.40 do 0.84 ) te učestalost ranog neuspjeha $\mathrm{u}$ liječenju teških (RR $0.32,95 \%$ CI 0.15 do 0.7 ) i lakših (RR 0.68, 95\% CI 0.56 do 0.83 ) oblika pneumonije. Potreba za mehaničkom ventilacijom, razvoj septičkog šoka i piogene komplikacije također su bili manje učestali kod skupine liječene kortikosteroidima (RR 0.58, 95\% CI 0.40 do 0.84) te su, sukladno tome, vrijeme hospitalizacije i vrijeme liječenja u JIL-u vidno skraćeni. Nisu zabilježene ozbiljnije nuspojave, osim povećane učestalosti prolazne hiperglikemije (RR 1.72, 95\% CI 1.38 do 2.14).

Iako se na temelju objavljenih rezultata gore navedene metaanalize činilo kako je korisnost kortikosteroida u liječenju teške pneumonije nedvojbeno potvrđena, druga metaanaliza objavljena u časopisu Clinical Infectious Diseases (Briel et al.) nepunih godinu dana kasnije i koja je uključivala randomizirane studije iz istog vremenskog perioda, nije rezultirala toliko op- timističim zaključcima. ${ }^{[14]} \mathrm{Na}$ temelju 6 uključenih randomiziranih studija s ukupno 1506 bolesnika, pronađeno je tek statistički nesignifikantno smanjenje smrtnosti, ali kao i u prethodnoj metaanalizi, i statistički značajno skraćenje vremena do postizanja kliničkog odgovora i skraćenje vremena hospitalizacije. Od nuspojava je, također, zabilježena prolazna hiperglikemija. Međutim, metaanaliza je, također, pokazala kako primjena kortikosteroida dovodi do učestalije ponovne hospitalizacije zbog pneumonije unutar 30 dana (aOR, 1.85; 95\%, CI 1.03 - 3.32; $P=0.04$ ), što je u skladu s ranije spomenutim studijama koje opisuju kasno pogoršanje i reaktivaciju upale nakon prekida liječenja kortikosteroidima kod određenih skupina bolesnika, pogotovo bolesnika s pneumokoknom pneumonijom. Studija autora Snijders et al. iz 2010. godine uključena je u ovu metaanalizu. Osim ponovne hospitalizacije zbog pneumonije, postoje i drugi rizici primjene kortikosteroida koji mogu dovesti do stanja koja zahtijevaju hospitalizaciju. Studija iz 2017. godine (Waljee et al.) sugerira da čak i kratkotrajno liječenje kortikosteroidima zbog bilo koje indikacije, u dozi prednozona manjoj od $20 \mathrm{mg} /$ dan i u trajanju kraćem od 30 dana dovodi do povećanog rizika za razvoj sepse (RR 5.30, 95\% CI 3.80 do 7.41), duboke venske tromboze (RR 3.33, 95\% CI 2.78 do 3.99) i fraktura (RR 1.87, 95\% CI 1.69 do 2.07) do 30 dana od početka liječenja, uz postupan pad rizika tijekom sljedećih 60 dana. ${ }^{[15]}$

Kada se sve navedeno uzme u obzir, može se zaključiti da, iako je većina studija pokazala bar nekakav pozitivan učinak kortikosteroida u smislu bržeg postizanja kliničke stabilnosti, skraćenja trajanja antimikrobne terapije ili skraćenja trajanja hospitalizacije, $\mathrm{u}$ većini nije pronađena statistički značajna razlika $\mathrm{u}$ smrtnosti te je pitanje rizika od kasnog pogoršanja i ponovne hospitalizacije ostalo otvoreno, što pak dovodi $\mathrm{u}$ pitanje ekonomsku isplativost dodavanja kortikosteroida. Također se većina studija slaže da je eventualna korisnost kortikosteroida, ukoliko je uopće realna, najizglednija kod bolesnika s teškom pneumonijom. Stoga, recentne smjernice objavljene od strane američkih stručnih društava Infectious Diseases Society of America (IDSA) i American Thoracic Society (ATS) te britanskog National Institute for Health and Care Excellence (NICE) iz 2019. godine ne preporučuju rutinsku primjenu kortikosteroida u liječenju pneumonije, čak ni teške pneumonije. ${ }^{[16],[17]}$ Svejedno, usprkos smjernicama, određeni broj stručnjaka i dalje preporučuje kortikosteroide za tešku pneumoniju i smatra kako pojedine skupine bolesnika vjerojatno imaju koristi od kortikosteroida, ali na temelju objavljenih istraživanja, ne može se sa sigurnošću zaključiti 
koji su to bolesnici. I dalje vrijedi konsenzus da se bolesnici s virusnim pneumonijama, pogotovo influenca pneumonijom ne liječe korikosteroidima zbog rizika od lošijeg ishoda. ${ }^{[1]]}$

Usprkos brojnim studijama, i dalje je ostao velik broj otvorenih pitanja, što se bar djelomično može pripisati velikim razlikama u strukturi i provedbi studija. Među nedostacima i ograničavajućim faktorima koje valja spomenuti, prvenstveno se ističe činjenica da je u različitim studijama različito definirana ozbiljnost odnosno stupanj bolesti. Nerijetko su bolesnici koji bi, primjerice, po PSI sustavu imali srednje tešku pneumoniju svrstani u skupinu teške pneumonije. Nadalje, postoje velike razlike u odabiru kortikosteroida, dozi i trajanju liječenja, čime se dodatno otežava donošenje jedinstvenog zaključka, pogotovo s obzirom na različit stupanj antiinflamatornog i mineralkortikoidnog djelovanja pojedinih kortikosteroida.

Također, budući da je etiologija pneumonije u većini slučajeva bila nepoznata, bilo je teško procijeniti razlike u djelotvornosti kortikosteroida ovisno o etiologiji. Jedino se ističu podatak o lošem učinku u pneumokoknoj pneumoniji u nekoliko ranije spomenutih studija i zaključak da se bolesnici s virusnim pneumonijama ne bi trebali liječiti kortikosteroidima.

Brojne ispitivane varijable, poput vremena do normalizacije tjelesne temperature, izravno ovise o antipiretičkom i drugim simptomatskim učincima kortikosteroida, a nemaju utjecaja na krajnji ishod liječenja. Također, iz većine su studija unaprijed isključeni bolesnici s povećanim rizikom od nuspojava kortikosteroida, poput imunosuprimiranih, onih s dijabetesom melitusom ili recentnim gastrointestinalnim krvarenjem.

Zaključno, usprkos dojmu da primjena kortikosteroida u određenoj mjeri ima pozitivan učinak na liječenje pneumonije i da prema recentnim studijama skraćuje vrijeme hospitalizacije i vrijeme do postizanja kliničke stabilnosti, još uvijek nema dovoljno dokaza na temelju kojih bi se decidirano mogla preporučiti njihova rutinska primjena. Najbitnije je da još uvijek nije potvrđen učinak kortikosteroida na smanjenje smrtnosti, ali uz to ostaje još uvijek velik broj otvorenih pitanja, poput identifikacije pacijenata kod kojih rizik nadilazi potencijalnu korist te pitanja odabira optimalnog lijeka, doze, trajanja liječenja, možebitnih nuspojava i povećanog rizika od ponovne hospitalizacije.

Također, vrijedi istaknuti kako su sve studije navedene u ovom članku uključivale isključivo bolesnike $s$ pneumonijom iz opće populacije. Vrlo se malo studija bavilo pedijatrijskom populacijom, a još manje liječenjem bolničkih pneumonija, uključujući pneumoniju povezanu s mehaničkom ventilacijom.

\section{Glavni zaključci:}

- Kortikosteroidi bi mogli imati određeni pozitivan utjecaj na liječenje pojedinih oblika teške pneumonije

- Nije dovoljno poznato kod kojih je skupina bolesnika potencijalna korist primjene kortikosteroida veća od rizika

- Potrebno je definirati optimalni odabir lijeka, dozu i trajanje liječenja

\section{LITERATURA}

${ }^{[1]}$ Mathers C, Stevens G, Hogan D, et al. Global and Regional Causes of Death: Patterns and Trends, 2000-15. In: Jamison DT, Gelband H, Horton S, et al., editors. Disease Control Priorities: Improving Health and Reducing Poverty. 3rd edition. Washington (DC): The International Bank for Reconstruction and Development / The World Bank; 2017 Nov 27. Chapter 4. Available from: https://www.ncbi.nlm.nih.gov/books/ NBK525280/.

${ }^{[2]}$ Tudose C, Moisoiu A, Bogdan M. Mortality Risk and Etiologic Spectrum of Community-acquired Pneumonia in Hospitalized Adult Patients. Maedica (Buchar) 2010;5:258-64.

${ }^{[3]}$ Fine MJ, Smith MA, Carson CA, et al. Prognosis and outcomes of patients with community-acquired pneumonia. A metaanalysis. JAMA 1996;275:134-141.

${ }^{[4]}$ Lorenzo MJ, Moret I, Sarria B, et al. Lung inflammatory pattern and antibiotic treatment in pneumonia. Respir Res. 2015; 16:15.

${ }^{[5]}$ McGee S, Hirschmann J. Use of corticosteroids in treating infectious diseases. Arch Intern Med 2008;168:1034-1046.

${ }^{[6]}$ de Gans J, van de Beek D; European Dexamethasone in Adulthood Bacterial Meningitis Study Investigators. Dexamethasone in adults with bacterial meningitis. N Engl J Med 2002;347:1549-1556.

${ }^{[7]}$ Snijders D, Daniels JM, de Graaff CS, van der Werf TS, Boersma WG. Efficacy of corticosteroids in community-acquired pneumonia: a randomized double-blinded clinical trial. Am J Respir Crit Care Med 2010;181:975-982.

${ }^{[8]}$ Torres A, Sibila O, Ferrer M, et al. Effect of corticosteroids on treatment failure among hospitalized patients with severe community-acquired pneumonia and high inflammatory response: a randomized clinical trial. JAMA. 2015;313:677686.

${ }^{[9]}$ Meijvis SC, Hardeman H, Remmelts HH, et al. Dexamethasone and length of hospital stay in patients with community-acquired pneumonia: a randomised, double-blind, placebo-controlled trial. Lancet 2011;377(9782):2023-2030.

${ }^{[10]}$ Wirz SA, Blum CA, Schuetz P, et al. Pathogen- and antibiotic-specific effects of prednisone in community-acquired pneumonia. Eur Respir J 2016;48:1150-1159.

${ }^{[11]} \mathrm{Ni}$ YN, Chen G, Sun J, Liang BM, Liang ZA. The effect of corticosteroids on mortality of patients with influenza pneumonia: a systematic review and meta-analysis. Crit Care 2019; 23:99. 
${ }^{[12]}$ Garcia-Vidal C, Calbo E, Pascual V, Ferrer C, Quintana S, Garau J. Effects of systemic steroids in patients with severe community-acquired pneumonia. Eur Respir J. 2007;30: 951956.

${ }^{[13]}$ Stern A, Skalsky K, Avni T, Carrara E, Leibovici L, Paul M. Corticosteroids for pneumonia. Cochrane Database of Systematic Reviews 2017, Issue 12. Art. No.: CD007720.

${ }^{[14]}$ Briel M, Spoorenberg SMC, Snijders D, et al. Corticosteroids in Patients Hospitalized With Community-Acquired Pneumonia: Systematic Review and Individual Patient Data Metaanalysis. Clin Infect Dis. 2018;66:346-354.
${ }^{[15]}$ Waljee AK, Rogers MA, Lin P, et al. Short term use of oral corticosteroids and related harms among adults in the United States: population based cohort study. BMJ. 2017;357:1415.

${ }^{[16]}$ Metlay JP, Waterer GW, Long AC, et al. Diagnosis and Treatment of Adults with Community-acquired Pneumonia. An Official Clinical Practice Guideline of the American Thoracic Society and Infectious Diseases Society of America. Am J Respir Crit Care Med. 2019;200:e45-e67.

${ }^{[17]}$ NICE guideline. Pneumonia (community-acquired): antimicrobial prescribing. Published date: 16 September 2019. Available at https://www.nice.org.uk/guidance/ng138 